\title{
The Reduction of the Chromosomes in the Sexual Cells as described by Botanists: A reply to Professor Strasburger.
}

\author{
BV \\ DR. VALENTIN HAECKER, \\ Zoological Institute, Freiburg-im-Breisgau.
}

I $\mathrm{N}$ a paper communicated to the British Association (Oxford Meeting, August, I894) ${ }^{1}$ Professor Strasburger attempts, first, to prove that in plants the reduction of the number of the chromosomes takes place at a certain point of the generative cell-cycle; and, secondly, to throw light upon the phylogenetic origin of that phenomenon. Convinced that there must be a close parallelism between animals and plants, Strasburger has extended his conclusions even to zoological territory, and generalized some of his theses in this direction. Undoubtedly such a generalization must be the goal which we strive to reach ; but in the first place let us see if the facts brought before us by zoological and botanical observers harmonize when carefully examined. Considering the great interest which is accorded to this subject by English botanists,

1 Compare: E. Strasburger, The Periodic Reduction of the number of the Chromosomes in the Life-History of Living Organisms, Ann. of Bot., Vol. viii, No. XXXI, I 894 ; Über periodische Reduktion der Chromosomenzahl im Entwicklungsgang der Organismen, Biol. Centralbl., Vol. xiv, Nos. 23 and 24, 1894.

[Annals of Botany, Vol. IX. No. XXXIII. March, I895.] 
one may perhaps be justified in directing their attention to the results attained by German zoologists.

I will confine myself in the following pages to the two questions; - at which point and in what manner the reduction of the number of the chromosomes takes place.

Strasburger attempts to show that in the Angiosperms 'the reduction takes place directly, both in the mother-cells of the pollen and in the mother-cell of the embryo-sac, and in such a manner that the reduced number of chromosomes is at once apparent in the prophase-stage.' The reduced number is retained during the subsequent divisions until the formation of the nucleus of the ovum and of the spermatic nucleus. Then the original number of chromosomes is re-established by the union of both elements.

To give an example, Guignard has shown that in Lilium, in all the nuclear divisions which are to be found in the pollensac and in the ovule, twenty-four chromosomes are visible. The framework of the resting nucleus of the pollen-mothercell and of the embryo-sac mother-cell is therefore constructed of twenty-four chromosomes; yet in the next prophase it nevertheless uniformly gives rise to only twelve chromosomes.

How is this reduction accomplished? Strasburger inclines towards the theory of the individuality of the chromosomesthat is to say, he would like to assume that these are 'always the same chromosomes, which make their appearance over and over again in the repeated divisions.' Therefore he assumes, in order to explain the direct 'reduction,' that the diminution of the number of chromosomes by half is due to the fusion into one of two chromosomatic individuals.

I believe that by assuming such a fusion the process of reduction is robbed of all theoretical significance, as far as such significance bears upon the theory of heredity. But I will not touch on this question, preferring rather to keep to the main subject.

Strasburger believes it to be proved that also in the mothercells of the ova and spermatozoa of animals the reduction 
is accomplished in the same manner as it seems to him to take place in Phanerogams. The reduction in animals takes place, as he thinks, in the mother-cells, and the chromosomes therefore already appear in the reduced number at the beginning of the two maturation-divisions. Each of the chromosomes undergoes double longitudinal splitting, by which they are prepared at the same time for both divisions. He believes, however, that there exists a complete homology between the botanical and zoological observations. Strasburger even asserts decidedly that reduction-divisions (Reduktionstheilungen) in Weismann's sense do not exist, either in plants or anywhere ${ }^{1}$, that is to say, such divisions in which the repartition of the chromosomes takes place without a preceding longitudinal splitting.

The question is, if the matter can be settled in this way or not. With regard to the literature relating to this subject, Strasburger refers us to his work, 'Schwärmsporen, Gameten, pflanzliche Spermatozoiden und das Wesen der Befruchtung.' This work was published in 1892 . During the last years, however, a series of papers ${ }^{2}$ have been published which promise a solution of the problem of reduction in a perfectly contrary direction.

In these papers it is partly indirectly concluded from comparison with other processes of division, partly proved by direct observation, that the two maturation-divisions are not introduced by a double longitudinal splitting, but only by

1 Compare Über periodische Reduktion u.s.w., Biol. Centralbl., xiv. p. ${ }_{55}$ I. In the English translation, Annals of Botany, viii. p. 310, Strasburger more cautiously says, 'Such divisions do not take place among plants.'

${ }^{2}$ (I) O. vom Rath, Zur Kenntniss der Spermatogenese von Gryllotalpa vulgaris, Latr. Arch. f. mikr. An., V. 40, I892 ; (2) V. Haecker, Die heterotypische Kerntheilung im Cyklus der generativen Zellen, Ber. Naturf. Ges. Freib., V. 6, I892 ; (3) V. Haecker, Das Keimbläschen, seine Elemente und Lageveränderungen I, Arch. f. mikr. An., V. 4I, I893; (4) O. vom Rath, Beiträge zur Kenntniss der Spermatogenese von Salamandra maculosa, Zeitschr. f. wiss. Zool., V. 57, I893 ; (5) V. Haecker, Über generative und embryonale Mitosen, Arch. f. mikr. An., V. 43, I894; (6) J. Rüickert, Zur Eireifung bei Copepoden, Anat. Hefte, V. 4, I894; (7) J. Ruickert, Die Chromatinreduktion bei der Reifung der Sexualzellen, Ergebn. d. An. und Entw. (Merkel u. Bonnet), V. 3, 1894. 
a single one ; and, further, that the second division is accomplished in this way-that every two elements, lying one behind the other in the original chromatic thread, are distributed in the two nuclei.

I should like to repeat a scheme, of which I have made use in a former paper and which has lately been also accepted by Rückert. If we signify the chromosomes (Idants of Weismann), lying one behind the other in the connecting thread, by $a, b, c, d \ldots$, the scheme of the longitudinally split thread is written thus:

$$
\frac{a b c d \ldots}{a b c d \ldots} \text {. }
$$

For example, if the 'normal' number of chromosomes is twenty-four, the scheme is the following:

$$
\frac{a b c d \ldots v x}{a b c d \ldots w x}
$$

When the generative cell begins the process of division, from this thread are separated the well-known tetrads (Vievergruppen):

$$
\frac{a b}{a b}, \frac{c d}{c d}, \ldots \frac{w x}{w x}
$$

In the first division they are disjoined in this way:

$$
\begin{aligned}
& \text { I. } a b \quad c d \quad w x \text { (=egg-nucleus) } \\
& \uparrow \uparrow, \ldots \uparrow \\
& \text { II. } a b \quad c d \quad w x \text { (=first polar body). }
\end{aligned}
$$

In the second division the double elements are disjoined into their units (reduction-division). From every pair, therefore, one element passes into the one nucleus, the second into the other. It has not yet been decided if there is a constant rule in the distribution, and I think it will never be decided; but we could assume, for example, that the distribution takes place in this way: 


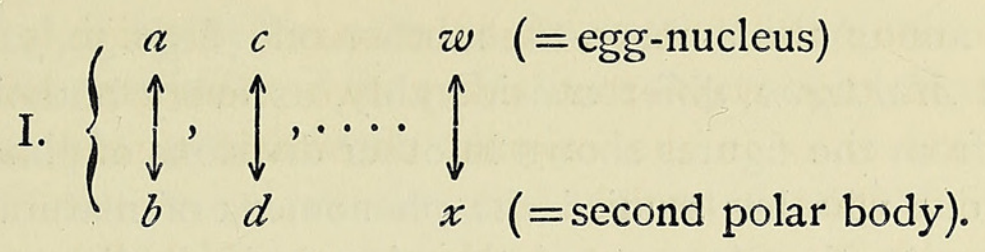

That the formation of the tetrads is accomplished in the manner above mentioned is clearly shown, chiefly by the observations of vom Rath and Ruickert. I myself shall shortly be able to demonstrate the process by a specially typical case, and to show that, even if there exist certain variations, the principle of the process remains the same ${ }^{1}$.

Thus it is permitted to assume, as a matter of fact, that reduction-divisions exist in the generative cells of animals. It may be even asserted as highly probable that their occurrence in the formation of the ova and spermatozoa of animals is a general phenomenon ${ }^{2}$. Thus it is a fact that at present the observations of the botanists and zoologists do not agree at all, and therefore cannot form a common basis for theoretical conclusions.

In making a generalizing theory, however, one is either obliged to enforce the observations of the one or the other side, or at least to assume incompleteness of observation. The zoologist will propose to himself two questions: first, if perhaps some of the figures given by botanists resemble the processes of reduction observed in animals, so that it may be assumed that the botanists have possibly overlooked certain stages ; and, secondly, if the kind of direct diminution of the chromosomes, as described by the botanists, is also to be observed in the generative cells of animals.

With regard to the first question I venture only to make one supposition. The figures which Guignard ${ }^{3}$ has given for the first division of the pollen-mother-cell (compare Figs. 12,

${ }^{1}$ Compare Die Vorstadien der Eireifung, Arch. f. mikr. An., V. 45 , I895.

2 There is at the present day only one observation which directly opposes this generalization. Compare A. Brauer, Zur Kenntniss der Spermatogenese von Ascaris megalocephala, Arch. f. mikr. Anat., V. 42, I893.

${ }^{3}$ L. Guignard, Nouvelles études sur la fécondation, Ann. d. sc. nat., Bot., I 891 . 
I 3, I4) and of the embryo-sac-mother-cell (Figs. 50, 52, 54) of Lilium Martagon, differ considerably, as every botanist will agree, from the figures shown in other divisions of plant-cells. Every one who has studied the phenomena of maturation in Arthropods, the changes of the chromatin in the germinal vesicle and the processes preparing the formation of the tetrads, thinks involuntarily of these observations while contemplating Guignard's figures ${ }^{1}$. And so I believe if a true reduction of the chromosomes takes place anywhere in the generative cell-cycle of plants it must exist there. At all events the zoologist is justified in doubting if all possibility of misinterpretation of the results obtained by the botanists is excluded, as Strasburger believes, at least so long as we are presented only with botanical investigations, which are interpreted without knowledge of the newer zoological facts.

The second question which has been mentioned seems to be already solved. Divisions in which a diminution of the number of the chromosomes takes place during the restingstage of the nucleus are well known to zoologists, at least they occur in embryonic cells, and chiefly in the generative cell-cycle. But it has been already shown, at least in several cases, that the reduction of the number of chromosomes is only apparent; that is to say, it could be demonstrated that during the prophase pairs of elements remain joined one with the other, and that they are only separated in the later stages. After this phenomenon had been established for special cases, it was easy to regard other divisions also in which half the number of chromosomes appears, chiefly the so-called 'heterotypic' divisions, as 'plurivalent' divisions; that is to say, as divisions in which each element is composed of two normal elements. I made this attempt some time ago, and vom Rath and Rückert have accepted this assumption. Ruickert has proposed for such cases the term 'pseudoreduction.' It would be too detailed to prove that assumption

${ }^{1}$ Compare J. Ruickert, Zur Eireifung bei Copepoden, tab. XXI-XXII (Ovogenesis in Cyclops strenuus). 
anew, but it would be, perhaps, interesting if botanists would weigh the possibility of the reductions observed by them being perhaps only 'pseudo-reductions.'

In a former paper ${ }^{1}$ Strasburger has pointed out that botanists and zoologists who are studying the processes of cell-division must work together. In regard to the problem of reduction, this relation seems to be lost for the moment ; but I doubt not that a few happy discoveries will suffice to rehabilitate the close parallelism between the animal and vegetable kingdoms.

1 E. Strasburger, Zu dem jetzigen Stande der Kern- und Zelltheilungsiragen ; Anat. Anz., I 893 . 


\section{$2 \mathrm{BHL}$ Biodiversity Heritage Library}

Haecker, Valentin. 1895. "The reduction of the chromosomes in the sexual cells as described by botanists: a reply to professor Strasburger." Annals of botany 9, 95-101. https://doi.org/10.1093/oxfordjournals.aob.a090735.

View This Item Online: https://www.biodiversitylibrary.org/item/233478

DOI: https://doi.org/10.1093/oxfordjournals.aob.a090735

Permalink: https://www.biodiversitylibrary.org/partpdf/318367

\section{Holding Institution}

Smithsonian Libraries

\section{Sponsored by}

Biodiversity Heritage Library

\section{Copyright \& Reuse}

Copyright Status: Not in copyright. The BHL knows of no copyright restrictions on this item.

This document was created from content at the Biodiversity Heritage Library, the world's largest open access digital library for biodiversity literature and archives. Visit BHL at https://www.biodiversitylibrary.org. 